A

STUDIA Z PRAWA WYZNANIOWEGO

Tom $23-2020$

DOI: https://doi.org/10.31743/spw.10656

\author{
MARCIN OLSZÓWKA* \\ KONRAD DYDA*
}

\title{
ANALIZA KONSTYTUCYJNOŚCI OGRANICZEŃ \\ W KORZYSTANIU Z WOLNOŚCI RELIGII \\ PODCZAS PANDEMII KORONAWIRUSA W POLSCE
}

\author{
Streszczenie
}

Konieczność przeciwdziałania rozwojowi pandemii koronawirusa SARS-CoV-2 wiąże się z koniecznością zachowania dystansu fizycznego oraz przestrzegania różnego rodzaju norm sanitarnych. Jednak w przypadku, gdy obostrzenia wprowadzane przez władze publiczne prowadzą do ograniczeń w korzystaniu z praw i wolności człowieka, muszą być ustanawiane w aktach normatywnych o odpowiedniej formie i treści. Tymczasem wiele z restrykcji wprowadzonych przez polskie władze w celu walki z pandemią, które limitowały korzystanie z wolności religii, nie spełniały standardów określonych przez Konstytucję RP.

Słowa kluczowe: wolność religii; ograniczenie korzystania z wolności religii; pandemia; zasada proporcjonalności; autonomia związków wyznaniowych; SARS-CoV-2; COVID-19

$* * * * *$

Niniejszy tekst stanowi zmienioną i zaktualizowaną wersję analizy opublikowanej 15 maja 2020 r. na stronie internetowej Instytutu na rzecz kultury prawnej Ordo Iuris: https://ordoiuris.pl/wolnosci-obywatelskie/analiza-zgodnosci-z-konstytucja-rp-ograniczen-w-korzystaniu-z-wolnosci.

* Dr, Katedra Prawa Administracyjnego, Konstytucyjnego i Prawa Pracy, Wydział Prawa i Administracji, Uczelnia Łazarskiego, ul Świeradowska 43, 02-662 Warszawa, e-mail: marcin.olszowka@lazarski.pl. ORCID 0000-0001-8280-5088.

*** Mgr lic., Katedra Prawa Wyznaniowego, Wydział Prawa, Prawa Kanonicznego i Administracji, Katolicki Uniwersytet Lubelski Jana Pawła II, Al. Racławickie 14, 20-950 Lublin, e-mail: konrad.dyda@gmail.com. ORCID: 0000-0002-2061-7839. 


\section{UWAGI WSTĘPNE}

Pandemia koronawirusa SARS-CoV-2, która rozpoczęła się na przełomie 2019/2020 r., spowodowała konieczność wprowadzenia - w większości państw świata - różnego rodzaju, nieraz bardzo drastycznych, ograniczeń w korzystaniu z praw człowieka, wśród nich z wolności religii. Podstawowym celem tego rodzaju obostrzeń, a nawet zupełnego uniemożliwienia publicznego praktykowania religii, zwłaszcza poprzez uczestnictwo w obrzędach kultowych, było zahamowanie rozprzestrzeniania się nowego patogenu. Nie inaczej było w Polsce, gdzie organy władzy wykonawczej zdecydowały się - najpierw w ramach stanu zagrożenia epidemicznego, a następnie stanu epidemii - na daleko idące ograniczenia w publicznym praktykowaniu religii.

Nie ma wątpliwości, że w demokratycznym państwie prawa władze publiczne - nawet w imię słusznych celów, jak ochrona zdrowia - nie mogą postępować w sposób dowolny, a wszelkie ograniczenia w korzystaniu z praw człowieka muszą być wprowadzone na mocy przepisów uchwalonych w odpowiedniej formie i treści. Dotyczy to zwłaszcza praw o charakterze fundamentalnym, a do takich zalicza się wolność religii.

Celem niniejszego artykułu jest ocena zgodności z Konstytucją $\mathrm{RP}^{1}$ zarówno pod względem materialnym, jak i formalnym - wprowadzonych w Polsce ograniczeń w korzystaniu z wolności religii. Analizie zostały poddane restrykcje obowiązujące w okresie od 13 marca do 29 maja 2020 r., a więc wprowadzone w pierwszym okresie walki z trwającą pandemią, niemniej zaprezentowane tu ustalenia odnośnie do treści normatywnej ustawy zasadniczej mają raczej charakter ,ponad- i pozaepidemiczny”.

\section{NAJWAŻNIEJSZE OGRANICZENIA W KORZYSTANIU Z WOLNOŚCI RELIGII W ZWIĄZKU Z PANDEMIĄ KORONAWIRUSA SARS-COV-2 W POLSCE}

W Polsce organy władzy wykonawczej zdecydowały się na podejmowanie działań mających na celu zwalczanie epidemii koronawirusa SARS-

1 Konstytucja Rzeczypospolitej Polskiej z dnia 2 kwietnia 1997 r., Dz. U. z 1997 r. $\mathrm{Nr} 78$, poz. 483 z późn. zm. 
-CoV-2 w trybie ustawy z dnia 5 grudnia 2008 r. o zapobieganiu oraz o zwalczaniu zakażeń i chorób zakaźnych u ludzi², a dokładniej w ramach przewidzianego w tym akcie stanu zagrożenia epidemicznego oraz stanu epidemii. Zgodnie $\mathrm{z}$ definicją legalną stan zagrożenia epidemicznego oznacza sytuację prawną wprowadzoną na danym obszarze w związku z ryzykiem wystąpienia epidemii w celu podjęcia określonych w ustawie działań zapobiegawczych (art. 2 pkt 23), natomiast stan epidemii to sytuacja prawna wprowadzona na danym obszarze w związku z wystąpieniem epidemii w celu podjęcia określonych $\mathrm{w}$ ustawie działań przeciwepidemicznych i zapobiegawczych dla zminimalizowania skutków epidemii (art. 2 pkt 22). W przypadku gdy zagrożenie epidemiczne lub epidemia występuje na obszarze więcej niż jednego województwa, stan zagrożenia epidemicznego lub stan epidemii ogłasza i odwołuje, w drodze rozporządzenia, minister właściwy do spraw zdrowia $\mathrm{w}$ porozumieniu $\mathrm{z}$ ministrem właściwym do spraw administracji publicznej, na wniosek Głównego Inspektora Sanitarnego (art. 46 ust. 2).

Na podstawie tej ustawy Minister Zdrowia 13 marca 2020 r. wydał rozporządzenie w sprawie ogłoszenia na obszarze Rzeczypospolitej Polskiej stanu zagrożenia epidemicznego ${ }^{3}$, zgodnie z którym od 14 marca ograniczono sprawowanie kultu religijnego w miejscach publicznych, w tym w budynkach i innych obiektach kultu religijnego ( $\$ 5$ ust. 1 pkt 4), poprzez wprowadzenie limitu 50 uczestników - wliczając w to osoby sprawujące kult religijny ( $§ 6$ ust. 1 pkt 3 ). Ograniczenie to zostało podtrzymane w rozporządzeniu Ministra Zdrowia z dnia 20 marca 2020 r. w sprawie ogłoszenia na obszarze Rzeczypospolitej Polskiej stanu epidemii ${ }^{4}$ ( $\$ 7$ ust. 1 pkt 3 w zw. z $\S 6$ ust. 1 pkt 4).

Sytuacja uległa fundamentalnej zmianie w wyniku nowelizacji tego rozporządzenia dokonanej 24 marca 2020 r. ${ }^{5}$, która wprowadziła limit maksymalnie 5 osób uczestniczących w kulcie religijnym, nie licząc

2 Tekst jedn. Dz. U. z 2019 r., poz. 1239 z późn. zm., dalej: ustawa o zwalczaniu chorób zakaźnych.

3 Dz. U. z 2020 r., poz. 433 z późn. zm.

4 Dz. U. z 2020 r., poz. 491.

5 Rozporządzeniem Ministra Zdrowia z dnia 24 marca 2020 r. zmieniającym rozporządzenie w sprawie ogłoszenia na obszarze Rzeczypospolitej Polskiej stanu epidemii, Dz. U. z 2020 r., poz. 522. 
osób sprawujących kult religijny lub osób zatrudnionych przez zakład pogrzebowy w przypadku pogrzebu (§ 1 ust. 4). Należy zaznaczyć, że rozwiązanie to $\mathrm{w}$ praktyce oznaczało zupełne uniemożliwienie wiernym świeckim uczestnictwa w sprawowaniu liturgii i to w okresie celebracji Wielkiego Tygodnia (do Wielkiej Soboty), stanowiącego najważniejszy czas dla wszystkich kościołów i wspólnot chrześcijańskich. Te same obostrzenia zostały podtrzymane w rozporządzeniu Rady Ministrów z dnia 31 marca 2020 r. w sprawie ustanowienia określonych ograniczeń, nakazów i zakazów w związku z wystąpieniem stanu epidemii ${ }^{6}$, a potem przedłużone do 20 kwietnia $2020 \mathrm{r}^{7}$

Następnie na mocy rozporządzenia Rady Ministrów z 19 kwiet-

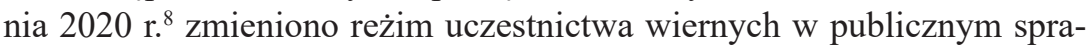
wowaniu kultu w świątyniach, wprowadzając regułę, zgodnie z którą w trakcie celebracji w budynku użyteczności publicznej przeznaczonym na potrzeby kultu religijnego może znajdować się 1 uczestnik na $15 \mathrm{~m}^{2}$ powierzchni tego budynku, oprócz osób sprawujących kult religijny. Natomiast w przypadku pogrzebu prawodawca zdecydował, że na cmentarzu może znajdować się nie więcej niż 50 uczestników podczas jednego pogrzebu, oprócz osób sprawujących kult religijny, osób dokonujących pochowania lub osób zatrudnionych przez zakład lub dom pogrzebowy ( 9 ust. 1 pkt 3 lit. b). Restrykcje te właściwie w całości powtórzono w obowiązującym do 16 maja 2020 r. - rozporządzeniu Rady Ministrów z 2 maja 2020 r. ${ }^{9}$ (§ 8 ust. 1 pkt 3). Jedyną modyfikacją było wprowadzenie reguły, zgodnie z którą w budynkach użyteczności publicznej przeznaczonych na potrzeby kultu religijnego o powierzchni mniejszej niż $75 \mathrm{~m}^{2}$ może

6 Dz. U. z 2020 r., poz. 566 z późn. zm.

7 Na mocy $\S 9$ ust. 2 rozporządzenia Rady Ministrów z dnia 10 kwietnia 2020 r. w sprawie ustanowienia określonych ograniczeń, nakazów i zakazów w związku z wystąpieniem stanu epidemii, Dz. U. z 2019 r., poz. 658, dalej: rozporządzenie z 10 kwietnia.

8 Rozporządzenie Rady Ministrów z dnia 19 kwietnia 2020 r. w sprawie ustanowienia określonych ograniczeń, nakazów i zakazów w związku z wystąpieniem stanu epidemii, Dz. U. z 2020 r., poz. 697, dalej: rozporządzenie z 19 kwietnia.

9 Rozporządzenie Rady Ministrów z dnia 2 maja 2020 r. w sprawie ustanowienia określonych ograniczeń, nakazów i zakazów w związku z wystąpieniem stanu epidemii, Dz. U. z 2020 r., poz. 792, dalej: rozporządzenie z 2 maja. 
jednocześnie przebywać maksymalnie 5 osób, za wyjątkiem sprawujących kult religijny ( $§ 8$ ust. 1 pkt 3 lit. a).

W rozporządzeniu Rady Ministrów z 16 maja 2020 r. ${ }^{10}$ (§ 8 ust. 1 pkt 3 lit. b) złagodzono od 17 maja 2020 r. restrykcje ilościowe poprzez wprowadzenie reguły: 1 wierny na $10 \mathrm{~m}^{2}$ powierzchni budynku użyteczności publicznej przeznaczonego na potrzeby kultu religijnego, oprócz osób sprawujących kult religijny, lecz utrzymano limit 50 uczestników na pogrzebie. Jednocześnie $\mathrm{w}$ świątyniach o powierzchni poniżej $50 \mathrm{~m}^{2}$ wprowadzono stały limit maksymalnie 5 osób, z wyjątkiem sprawujących kult religijny. Obostrzenia te przestały obowiązywać 30 maja 2020 r. $^{11}$

\section{FORMA, PRZESŁANKI I REGUŁY OGRANICZANIA KORZYSTANIA Z KONSTYTUCYJNYCH WOLNOŚCI I PRAW (,TRZY TESTY” ZASADY PROPORCJONALNOŚCI)}

Zasady ograniczania korzystania z wolności i praw człowieka gwarantowanych w Konstytucji - a więc granice ingerencji w nie organów władzy ustawodawczej, wykonawczej i sądowniczej ${ }^{12}$ - wyznacza przede wszystkim art. 31 ust. 3. Przepis ten - określany mianem ogólnej klauzuli limitacyjnej - stanowi, że ograniczenia w zakresie korzystania z konstytucyjnych wolności i praw mogą być ustanawiane tylko w ustawie i tylko wtedy, gdy są konieczne w demokratycznym państwie dla jego bezpieczeństwa lub porządku publicznego, bądź dla ochrony środowiska, zdrowia i moralności publicznej, albo wolności i praw innych osób. Ograniczenia te nie mogą naruszać istoty wolności i praw. Jednocześnie regulacja ta ma charakter podstawowy i co do zasady znajduje pełne zastosowanie do wszystkich praw i wolności poręczonych w ustawie zasadniczej. Innymi słowy, na mocy art. 31 ust. 3 Konstytucji, ograniczenie w korzystaniu z wolności

10 Rozporządzenie Rady Ministrów z dnia 16 maja 2020 r. w sprawie ustanowienia określonych ograniczeń, nakazów i zakazów w związku z wystąpieniem stanu epidemii, Dz. U. z 2020 r., poz. 878, dalej: rozporządzenie z 16 maja.

11 Na podstawie $\S 20$ rozporządzenia Rady Ministrów z dnia 29 maja 2020 r. w sprawie ustanowienia określonych ograniczeń, nakazów i zakazów w związku z wystąpieniem stanu epidemii, Dz. U. z 2020 r., poz. 964.

12 Por. Garlicki, Wojtyczek 2016, uwaga 20. 
i praw jest dopuszczalne tylko wówczas, gdy spełnia jasno zdefiniowane przez ustrojodawcę przesłanki formalne i materialne.

Ustawodawca konstytucyjny jednoznacznie zdecydował - co notabene jest charakterystyczne dla państwa prawa - że wprowadzenie restrykcji może zostać dokonane jedynie w drodze ustawy, co wyklucza możliwość regulowania tego rodzaju materii w drodze aktów o charakterze podustawowym, a więc np. w rozporządzeniu ${ }^{13}$ (,pierwszy test”). Bezdyskusyjne jest zatem, iż w obecnych realiach konstytucyjnych niedopuszczalne jest ograniczanie kogokolwiek w przysługujących mu wolnościach i prawach bez jednoznacznego przepisu ustawy. Wymóg ograniczenia wolności i praw ,tylko w ustawie" stawia przed prawodawcą nie tylko obowiązek wydania aktu normatywnego o określonej randze w systemie źródeł prawa, ale jednocześnie o odpowiedniej treści. Z tego względu taki przepis ustawy „musi samodzielnie określać wszystkie podstawowe elementy ograniczenia danego prawa i wolności, tak aby już na podstawie lektury przepisów ustawy można było wyznaczyć kompletny zarys (kontur) tego ograniczenia"14. W świetle art. 31 ust. 3 Konstytucji dopuszczalna jest co prawda sytuacja, gdy szczegółowy zakres wprowadzanych ograniczeń wynika $\mathrm{z}$ aktu o charakterze podustawowym (np. rozporządzenia, a nawet uchwały organu stanowiącego jednostki samorządu terytorialnego), jednak upoważnienie do wydania tego rodzaju aktu musi określać zarówno podstawowe elementy ograniczenia, jak i jego granicę. Dlatego tego rodzaju przepis ustawy musi wskazywać przynajmniej na to, jakie sposoby korzystania z danej wolności (np. udział w publicznym sprawowaniu obrzędów

13 Wyrok Trybunału Konstytucyjnego z 25 lipca 2006 r., sygn. akt P 24/05, OTK ZU 7A/2006, poz. 87, pkt III.2.

14 Wyroki Trybunału Konstytucyjnego z 12 stycznia 2000 r., sygn. akt P 11/98, OTK ZU 1/2000, poz. 9, pkt 6, pkt III.6B; 5 lutego 2008 r., sygn. akt K 34/06, OTK ZU 1A/2008, poz. 2, pkt III.2; powtórzone innymi słowami w wyrokach z: 8 lipca 2003 r., sygn. akt P 10/02, OTK ZU 6A/2003, poz. 62, pkt III.1; 5 grudnia 2007 r., sygn. akt K 36/06, OTK ZU 11A/2007, poz. 154 pkt III.4; 19 czerwca 2008 r., sygn. akt P 23/07, OTK ZU 5A/2008, poz. 82, pkt III.3; 19 maja 2009 r., sygn. akt K 47/07, OTK ZU 5A/2009, poz. 68, pkt III.3. Do tego rygoru w sposób mniej kategoryczny można podejść w odniesieniu do tych konstytucyjnych praw i wolności, które mają mniejsze znaczenie, np. praw socjalnych (Garlicki, Wojtyczek 2016, uwaga 31; Tuleja 2019, uwaga 2). 
religijnych) mogą zostać ograniczone oraz na jakich warunkach dopuszczalne jest wprowadzenie takiej limitacji.

Analizując przesłanki materialne ograniczenia możliwości korzystania z wolności i praw należy w pierwszym rzędzie podkreślić, że zostały one skatalogowane w sposób zamknięty. Oznacza to, że każde ograniczenie musi dokonać się $\mathrm{w}$ celu realizacji przynajmniej jednej z wymienionych w art. 31 ust. 3 Konstytucji przesłanek (o stosunkowo szerokiej treści) ${ }^{15}$, np. ze względu na ochronę zdrowia lub moralności publicznej („drugi test"). Trybunał Konstytucyjny zwraca uwagę - jak np. w wyroku dotyczącym ograniczeń konstytucyjnego prawa lekarzy do sprzeciwu sumienia - że „ocena przepisu ograniczającego konstytucyjną wolność nie polega na analizie poszczególnych przypadków (stanów faktycznych), w których dochodzi lub może dojść do kolizji wartości, lecz przebiega na poziomie tekstu prawnego, który powinien umożliwić jednoznaczne wskazanie konkurujących ze sobą wartości" ${ }^{16}$ oraz iż niedopuszczalne jest ograniczanie wolności konstytucyjnych, zwłaszcza takich jak wolność sumienia i religii, na podstawie sformułowań ogólnych, uniemożliwiających identyfikację wartości, ze względu na którą wprowadza się restrykcje. Tym samym wysoka ranga wolności sumienia i religii w konstytucyjnej hierarchii wolności i praw człowieka oznacza, że ograniczenie jej uzewnętrzniania musi być uzasadnione szczególnie ważnymi i odpowiednio udowodnionymi racjami ${ }^{17}$.

Nie ma więc najmniejszych wątpliwości, że samo przekonanie (nawet słuszne) władzy ustawodawczej o konieczności wprowadzenia restrykcji w żadnym wypadku nie jest wystarczające do ich legalności, nawet gdyby miało służyć zapewnieniu ochrony zdrowia innych osób czy całego społeczeństwa. Każde ograniczenie musi być konieczne w demokratycznym państwie. A zatem nie tylko przydatne, lecz również niezbędne do osiągnięcia tego celu (np. zapewnienia ochrony zdrowia, moralności publicznej), a równocześnie nie może prowadzić do zupełnego pozbawienia możliwości korzystania z konstytucyjnych wolności i praw. Ten wymóg można

15 Lub wyjątkowo w innym przepisie ustawy zasadniczej, o czym szerzej w dalszej części artykułu.

16 Wyrok Trybunału Konstytucyjnego z 7 października 2015 r., sygn. akt K 12/14, OTK ZU 9A/2015, poz. 143, pkt III.5.3.3.

17 Wyrok Trybunału Konstytucyjnego z 10 grudnia 2014 r., sygn. akt K 52/13, OTK-A 2014, Nr 11, poz. 118, pkt III.8.3. 
określić jako „trzeci test”, który musi spełnić każde ustanowione przez władzę publiczną ograniczenie, podobnie jak pozytywny być musi wynik badania, czy zostały spełnione przesłanki formalne (,pierwszy test”) oraz przesłanki materialne (,drugi test”).

Na podstawie przepisów ustawy zasadniczej, zwłaszcza odwołując się do wzorca demokratycznego państwa prawnego (art. 2 Konstytucji) i ogólnej klauzuli limitacyjnej (art. 31 ust. 3 Konstytucji), Trybunał Konstytucyjny konsekwentnie warunkuje dopuszczalność wprowadzenia ograniczeń konstytucyjnych praw i wolności pozytywną odpowiedzią na trzy pytania:

1) czy wprowadzona regulacja ustawodawcza jest w stanie doprowadzić do zamierzonych przez nią skutków (tzw. przydatność);

2) czy regulacja ta jest niezbędna dla ochrony interesu publicznego (wspomniane wyżej przesłanki materialne), z którym jest powiązana (tzw. konieczność);

3) czy efekty wprowadzanej regulacji pozostają w proporcji do ciężarów nakładanych przez nią na obywatela (tzw. proporcjonalność sensu stricto $)^{18}$.

Obostrzenia w korzystaniu z wolności konstytucyjnych tylko wtedy są konieczne w państwie demokratycznym - jak stanowi art. 31 ust. 3 Konstytucji - kiedy są przydatne i konieczne do realizacji jednej z wymienionych $\mathrm{w}$ tym przepisie wartości oraz pozostają adekwatne w stosunku do zakładanych skutków, czyli nie ingerują zbyt drastycznie. Jeżeli przynajmniej jeden z elementów testu proporcjonalności (,trzeciego testu”) nie zostaje zachowany, oznacza to wadliwość regulacji, która w konsekwencji oznacza jej niekonstytucyjność.

W omawianym przepisie ustrojodawca ustanawia jeszcze jeden obligatoryjny warunek - ściśle powiązany z proporcjonalnością sensu stricto - obostrzenia nie mogą naruszać istoty danej wolności, a więc swoistego ,jądra”, bez którego wolność lub prawo w ogóle nie mogą istnieć, stanowiącego jednocześnie o ich tożsamości ${ }^{19}$. W konsekwencji Trybunał

18 Orzeczenie Trybunału Konstytucyjnego z 26 kwietnia 1995 r., sygn. akt K 11/94, OTK ZU 1995, poz. 12, pkt III.2; cytowany m.in. w wyrokach Trybunału Konstytucyjnego z: 28 czerwca 2017r., sygn. aktP63/14,OTKZUA/2017, poz. 55, pkt III.5.2; 17 stycznia 2019r., sygn. akt K 1/18, OTK ZU A/2019, poz. 6, pkt III.2.4.1.3; 26 czerwca 2019 r., sygn. akt K 16/17, OTK ZU A/2019, poz. 49, pkt III.3.2.

19 Garlicki 2012, 103. 
Konstytucyjny wskazuje na istnienie „nieprzekraczalnych granic ingerencji państwa (przede wszystkim prawodawcy) w sferę gwarantowanych konstytucyjnie praw i wolności jednostki”20 k którą właśnie wyznacza istota danej wolności lub prawa. Z tego względu, badając konstytucyjną dopuszczalność konkretnego ograniczenia, należy określić istotę prawa (wolności), czyli nieprzekraczalny rdzeń, który nigdy nie może zostać naruszony. W przypadku, w którym wprowadzone ograniczenia budzą wątpliwości pod kątem zachowania zasady proporcjonalności („trzeciego testu”) - ale nie na tyle poważne, żeby stwierdzić niedopuszczalność regulacji - należy ustalić, czy nie godzą właśnie w istotę prawa (wolności), co jest w każdym przypadku niedopuszczalne ${ }^{21}$.

Jak już zostało zasygnalizowane, ogólna klauzula limitacyjna znajduje zastosowanie do wszystkich praw i wolności zagwarantowanych w Konstytucji. Jednocześnie ustrojodawca sformułował szczególne regulacje dotyczące ochrony określonych praw i wolności. Ich celem może być podniesienie standardu danej wolności (prawa), a więc zaostrzenie warunków - w stosunku do tych wynikających z art. 31 ust. 3 Konstytucji - jakie muszą zostać spełnione, aby prawodawca mógł ustanowić ograniczenie w korzystaniu z danej wolności (prawa) ${ }^{22}$. Przykładem zastosowania takiego rodzaju rozwiązania jest art. 53 ust. 5 Konstytucji, który stanowi, że wolność uzewnętrzniania religii może być ograniczona jedynie w drodze ustawy i tylko wtedy, gdy jest to konieczne do ochrony bezpieczeństwa państwa, porządku publicznego, zdrowia, moralności lub wolności i praw innych osób (art. 53 ust. 5$)^{23}$.

20 Wyrok Trybunału Konstytucyjnego z 11 maja 1999 r., sygn. akt K 13/98, OTK 1999, $\mathrm{Nr} 4$, poz. 74, pkt III.2.

21 Tuleja 2019, uwaga 2. Z tego powodu w judykaturze Trybunału Konstytucyjnego ten warunek bywa wskazywany jako odrębny, czwarty element zasady proporcjonalności tak np. wyrok z 19 grudnia 2002 r, sygn. akt K 33/02, OTK ZU 7A/2002, poz. 9, pkt III.12.

$22 \mathrm{~W}$ odniesieniu do art. 53 ust. 5 Konstytucji (wolność uzewnętrzniania religii) podkreślił to Trybunał Konstytucyjny w wyroku z 10 grudnia 2014 r., sygn. akt K 52/13, pkt III.7.2.

23 Ustrojodawca formułując szczególne klauzule limitacyjne nie zawsze ma na celu podkreślenie fundamentalnego charakteru danej wolności - jak to ma miejsce w przypadku wolności religii - i jej wysokiego miejsca w hierarchii wartości konstytucyjnych. Pod względem ilościowym szczególne klauzule limitacyjne częściej poszerzają katalog materialnych przesłanek ograniczeń danej wolności, np. w odniesieniu do prawa dostępu do 
Istotną różnicą między materialnymi kryteriami ograniczenia w korzystaniu z wolności i praw sformułowanymi w art. 31 ust. 3 i art. 53 ust. 5 Konstytucji jest katalog przesłanek, ze względu na które dopuszczalne jest dokonanie ograniczenia. W przypadku wolności uzewnętrzniania religii jej limitacja nie może nastąpić ze względu na ochronę środowiska. Zróżnicowanie przez ustrojodawcę ogólnych przesłanek ograniczania praw i wolności oraz szczególnych, dotyczących wolności uzewnętrzniania religii, dowodzi, że wolność ta ma charakter fundamentalnego prawa człowieka, któremu ustrojodawca, w ślad za standardami międzynarodowymi, przyznał wyjątkowy status. Raz jeszcze trzeba tu podkreślić, iż pozostałe wymogi wynikające z art. 31 ust. 3 Konstytucji (forma ustawy, test proporcjonalności i zakaz naruszania istoty) w pełni muszą być zachowane przy wprowadzaniu obostrzeń w korzystaniu z wolności uzewnętrzniania religii ${ }^{24}$. W rezultacie doniosłą rolę analizowanej wolności podkreśla Trybunał Konstytucyjny zwracający uwagę, że wolności wymienione w art. 53 ust. 1 zajmują szczególne miejsce wśród praw i wolności człowieka ${ }^{25}$.

Istotne znaczenie dla ochrony wolności religii ma także art. 25 ust. 3 Konstytucji, zapewniający związkom religijnym autonomię oraz wzajemną niezależność w „swoim zakresie”, który obejmuje m.in. określanie sposobów praktykowania i oddawania kultu religijnego oraz obowiązujące wier-

informacji publicznej (art. 61 ust. 3 Konstytucji), czyli pozwalają na dalej idące ograniczenia, co znajduje odzwierciedlenie w judykaturze Trybunału Konstytucyjnego (np. wyroki z: 18 lutego 2014 r., sygn. akt K 29/12, OTK-A 2014, Nr 2, poz.11, pkt III.2; 9 kwietnia 2015 r., sygn. akt K 14/13, OTK-A 2015, Nr 4, poz. 45, pkt III.3.2). Jak trafnie wskazuje się w literaturze przedmiotu: ,uznawać więc należy, że art. 31 ust. 3 pełni rolę uzupełniającą, a więc że znajdują zastosowanie te wszystkie jego elementy, które nie pokrywają się z uregulowaniem szczegółowym, bądź których uregulowania te nie wyłączyły w sposób wyraźny (...). W każdym więc wypadku, gdy między pewnymi fragmentami art. 31 ust. 3 a unormowaniem zawartym w przepisie szczegółowym zachodzi stosunek pokrywania się, «klauzule szczegółowe stanowią lex specialis i wyłączają zastosowanie art. 31 ust. 3» (Wojtyczek 1999, 81). Zawsze jednak pozostaną inne elementy art. 31 ust. 3 (zwłaszcza «granice ograniczeń»), których nie uwzględniono w przepisie szczegółowym i które nadal znajdować będą zastosowanie" (Garlicki, Wojtyczek 2016, uwaga 25).

24 Olszówka 2016b, 1273-1274.

25 Wyrok Trybunału Konstytucyjnego z 7 października 2015 r., sygn. akt K 12/14, pkt III.4.1.1. 
nych zasady moralne i religijne. Kwestie te, co do zasady, znajdują się poza kompetencjami państwa, a w rezultacie poza zakresem materialnym prawa powszechnie obowiązującego ${ }^{26}$. Art. 25 Konstytucji potwierdza również ustrojowe znaczenie wolności sumienia i religii. Ze względu na umiejscowienie tego przepisu w rozdziale I ustawy zasadniczej, zawierającym większość zasad ustrojowych, uprawniona jest konstatacja, iż w polskich realiach konstytucyjnych wolność religii jest nie tylko wolnością o charakterze osobistym, ale również zasadą ustrojową ${ }^{27}$. Skoro więc wolność sumienia i religii stanowi jedną z zasad ustrojowych Rzeczypospolitej Polskiej, jakiekolwiek jej ograniczenia powinny być poddawane surowszej ocenie, z uwzględnieniem okoliczności, iż mogą godzić w fundamenty porządku prawnego.

O podstawowym charakterze wolności religii w ustroju Trzeciej Rzeczypospolitej świadczą także przepisy rozdziału XI Konstytucji. Otóż zgodnie $\mathrm{z}$ art. 233 Konstytucji w czasie trwania któregokolwiek ze stanów nadzwyczajnych (wojennego, wyjątkowego, klęski żywiołowej) nie jest dopuszczalne ograniczenie wolności religii na zasadach innych niż ogólne, tj. z poszanowaniem art. 31 ust. 3 i art. 53 ust. 5 Konstytucji, czyli nie może być ono dalej idące. Dlatego w ustawie z dnia 18 kwietnia 2002 r. o stanie klęski żywiołowej ${ }^{28}$ (art. 20-26) nie przewidziano żadnych dodatkowych obostrzeń w korzystaniu z wolności religii. Również w stanach wyjątkowym i wojennym dopuszczalność restrykcji w tym zakresie jest daleko mniejsza niż w przypadku pozostałych wolności oraz praw i możliwa w zasadzie jedynie w postaci ograniczenia uroczystości religijnych mających miejsce poza budynkiem świątyni (np. procesji Bożego Ciała) ${ }^{29}$. Co więcej, w obu tych stanach nadzwyczajnych wolno wprowadzić cenzurę prewencyjną, ale nie może ona dotyczyć należących do kościołów i innych związków wyznaniowych środków społecznego przekazu, stanowią-

26 Olszówka 2016a, 671-673.

27 Wyrok Trybunału Konstytucyjnego z 10 grudnia 2014 r., sygn. akt K 52/13, pkt III.5.2.

28 Dz. U. z 2017 r., poz. 1897.

29 Art. 16 ust. 2 ustawy z dnia 21 czerwca 2002 r. o stanie wyjątkowym, Dz. U. z 2017 r., poz. 1928; art. 22 ust. 2 ustawy z dnia 29 sierpnia 2002 r. o stanie wojennym oraz o kompetencjach Naczelnego Dowódcy Sił Zbrojnych i zasadach jego podległości konstytucyjnym organom Rzeczypospolitej Polskiej, Dz. U. z 2017 r., poz. 1932. 
cych źródła informacji na temat religii i służących wypełnianiu funkcji religijnych ${ }^{30}$. Rozwiązania te potwierdzają, iż rzeczywistą wolą ustrojodawcy było uznanie wolności religii za jedną z zasad konstytucyjnych, której limitacja jest dopuszczalna w mniejszym stopniu niż w przypadku większości innych wolności i praw gwarantowanych w obowiązującej ustawie zasadniczej.

Nie sposób zatem pominąc ten aspekt analizując to, czy wprowadzane restrykcje dotyczące sprawowania kultu religijnego spełniają konstytucyjny test przydatności, konieczności i proporcjonalności sensu stricto (,trzeci test"). Podkreślenia wymaga również to, że uwarunkowania konstytucyjne powinny być brane pod uwagę nie tylko przy analizie hierarchicznej zgodności relewantnych przepisów, ale również na etapie ich stosowania. Wszak Konstytucję, będącą aktem normatywnym, stosuje się bezpośrednio, chyba że stanowi inaczej (art. 8 ust. 2). Oznacza to m.in. konieczność dokonywania wykładni prawa, która pozostaje w zgodzie z normami konstytucyjnymi. W praktyce może to oznaczać nawet odejście od wyników wykładni językowej, a nawet konieczność - z poszanowaniem art. 187 i 193 Konstytucji - niestosowania wadliwie ustanowionych przepisów.

\section{OCENA OGRANICZEŃ WOLNOŚCI RELIGII WPROWADZONYCH W RAMACH STANU ZAGROŻENIA EPIDEMICZNEGO I STANU EPIDEMII}

Analiza zgodności z Konstytucją obostrzeń w zakresie korzystania z wolności religii - podobnie, jak w przypadku właściwie każdej innej wolności bądź prawa - polega na ocenie, czy wprowadzone restrykcje odpowiadają wszystkim standardom określonym przez ustrojodawcę: a więc czy zostały wprowadzone w odpowiedniej formie (,pierwszy test”), ze względu na co najmniej jedną z wartości wymienionych w art. 53 ust. 5 Konstytucji („drugi test”), są przydatne i konieczne dla ochrony wartości, ze

30 Art. 20 ustawy o stanie wyjątkowym, art. 21 ustawy o stanie wojennym. Mówiąc bardzo obrazowo i w dużym uproszczeniu, w stanach wyjątkowym lub wojennym rząd może zamknąć TVN, ale nie może ograniczyć liczby wiernych przychodzących do kościoła (cerkwi, synagogi). 
względu na które je ustanowiono oraz czy pozostają adekwatne w danej sytuacji („trzeci test”), w tym nie przekreślają istoty wolności religii.

Ponieważ wymienione wyżej warunki muszą zostać spełnione kumulatywnie, nie ma w istocie znaczenia, w jakiej kolejności będzie badane ich zachowanie, aczkolwiek zazwyczaj jest przeprowadzane w kolejności wynikającej z numeracji „testów”, oddającej pewien ich logiczny porządek. Najczęściej, co jest zwłaszcza widoczne w judykaturze Trybunału Konstytucyjnego ${ }^{31}$, stwierdzenie niewypełnienia jednego z kryteriów powoduje, że nie przeprowadza się kolejnych „testów”, ponieważ jest już wiadome, że przepis prawa został wadliwie ustanowiony i powinien być uchylony ze wszystkimi tego skutkami prawnymi. Niemniej w niniejszym artykule, dla pełnego zobrazowania problemu, ocena konstytucyjności zostanie przeprowadzona kompleksowo, tzn. obejmie wszystkie „trzy testy".

W pierwszym rzędzie należy podnieść, że żaden przepis ustawy o zwalczaniu chorób zakaźnych nie upoważnia Ministra Zdrowia, żadnego innego ministra czy Rady Ministrów do wprowadzenia ograniczeń w korzystaniu z wolności religii (w tym limitów ilościowych) w związku z ogłoszeniem stanu zagrożenia epidemicznego lub epidemii, a tym bardziej do faktycznie zupełnego pozbawienia osób wierzących możliwości uczestnictwa $\mathrm{w}$ fundamentalnych dla nich praktykach religijnych (np. fizycznego wzięcia udziału w niedzielnej mszy św. w przypadku katolików) - bo tak należy traktować obowiązujący od 25 marca do 19 kwietnia 2020 r. limit 5 wiernych. Trzeba także zaznaczyć, iż jakikolwiek inny przepis polskiego ustawodawstwa nie zawiera takiego upoważnienia.

Właściwie jedynie przepisy, które mogłyby być rozważane przy uzasadnianiu wprowadzonych ograniczeń ilościowych w korzystaniu z wolności uzewnętrzniania religii, to uprawnienie ministra właściwego do spraw zdrowia (na podstawie art. 46b przysługujące także Radzie Ministrów) do czasowego ograniczenia - w ramach stanu zagrożenia epidemicznego bądź stanu epidemii - określonego sposobu przemieszczania się, czasowego ograniczenia funkcjonowania określonych instytucji lub

31 Zob. np. wyrok Trybunału Konstytucyjnego z 7 października 2015 r., sygn. akt K 12/14, pkt III.5.3 oraz III.6.2. 
zakładów pracy lub wprowadzenia zakazu organizowania widowisk i innych zgromadzeń ludności (art. 46 ust. 4 pkt 1, 3, 4 ustawy o zwalczaniu chorób zakaźnych). Jednak przepisy te trudno uznać za upoważaniające do ograniczenia wolności religii, gdyż dotyczą zupełnie innych materii, niepowiązanych z wolnością religii, która na gruncie konstytucyjnym i w konsekwencji - ustawodawstwa zwykłego jest wyraźnie odróżniana od innych wolności, w tym wolności zgromadzeń. Tezy tej nie zmienia przyjęcie w systematyce rozporządzeń, zarówno Ministra Zdrowia, jak i Rady Ministrów, że związki religijne to „instytucje lub zakłady pracy”, ponieważ są to odrębne kategorialnie podmioty prawa, którym Konstytucja w rozdziale I poświęca osobny, stosunkowo obszerny przepis (art. 25), gwarantujący im m.in. autonomię oraz wzajemną niezależność względem państwa. Godne podkreślenia jest, że takiego statusu nie posiadają żadne inne instytucje społeczeństwa obywatelskiego, o których wspomina polski ustrojodawca. Nie jest zatem dopuszczalne redukowanie statusu związków religijnych do kategorii podmiotów określanych zbiorczo jako, instytucje lub zakłady pracy". Upoważnienia do ingerencji w funkcjonowanie kościołów i innych związków wyznaniowych oraz wolność religii nie przewiduje także art. 46b ustawy o zwalczaniu chorób zakaźnych - odsyłający w tym zakresie wprost do art. 46 - na podstawie którego wydano rozporządzenia Rady Ministrów z 31 marca, 10 i 19 kwietnia oraz 2 i 16 maja 2020 r. Nie sposób zatem uznać, że w art. 46 ust. 4 pkt 1, 3, 4 lub art. 46b wspomnianej ustawy ustawodawca upoważnił do uznaniowego ograniczenia wolności uzewnętrzniania religii w drodze rozporządzenia. $Z$ art. 53 ust. 5 - jak i art. 31 ust. 3 - Konstytucji wynika bowiem konieczność ustawowej podstawy (a nawet wyłączności ustawy) ${ }^{32}$ dla ustanowienia restrykcji ograniczających wolność uzewnętrzniania religii.

32 Nie powielając w tym miejscu wcześniejszych rozważań trzeba skonstatować, iż w stosunku do wolności religii - ze względu na jej wysoką rangę w hierarchii dóbr konstytucyjnych - opisywany tu wymóg wyłączności ustawy powinien być przestrzegany w sposób bardziej rygorystyczny. Ze względu jednak na brak ustawowego upoważnienia do ograniczenia wolności uzewnętrzniania religii w stanie epidemii (zagrożenia epidemicznego), kwestia nieprzekraczalnych granic cedowania przez ustawodawcę materii do uregulowania w drodze rozporządzenia pozostaje zagadnieniem pozbawionym praktycznych konsekwencji dla przedmiotu analizy. 
Tym samym doszło również do naruszenia art. 92 Konstytucji, gdyż organy wydające rozporządzenie przekroczyły zakresy upoważnień ustawowych zawartych w ustawie o zwalczaniu chorób zakaźnych ${ }^{33}$. Nie zmienia tego fakt, że autorzy rozporządzeń powołują się na ustawę, ponieważ ta nie upoważnia nikogo do wprowadzenia ograniczeń w korzystaniu z wolności religii. Zgodnie z Konstytucją, brak wyraźnego stanowiska ustawodawcy co do zakresu spraw przekazanych do uregulowania musi być interpretowany jako nieudzielenie $\mathrm{w}$ danym zakresie kompetencji normodawczej ${ }^{34}$. Nie można jej bowiem domniemywać czy wyinterpretowywać z przepisów ustawy dotyczących co prawda kwestii, które organ reguluje w rozporządzeniu, jednak niezawierających jakiegokolwiek upoważnienia do podjęcia aktywności prawodawczej w innych obszarach. Tym samym wszystkie ograniczenia ilościowe w sprawowaniu kultu religijnego (chronologicznie: 50 osób, 5 wiernych, 1 uczestnik na $15 \mathrm{~m}^{2}$, potem $10 \mathrm{~m}^{2}$ powierzchni miejsca kultu) zostały wprowadzone bez podstawy ustawowej, a więc nie spełniają „testu pierwszego". To właściwie mogłoby zamknąć analizę - jednak, jak zostało już wspomniane, ze względu na złożoność zagadnienia, warto rozważyć dopuszczalność wprowadzonych ograniczeń w korzystaniu z wolności religii w czasie pandemii z punktu widzenia pozostałych „testów”.

Z perspektywy przesłanki materialnej dopuszczalność ustanawiania ograniczeń $\mathrm{w}$ korzystaniu $\mathrm{z}$ gwarantowanych konstytucyjnie wolności i praw w celu przeciwdziałania rozprzestrzeniania się koronawirusa SARS-CoV-2 nie podlega wątpliwości. Wynika to z obowiązku władz publicznych ochrony wolności i praw innych osób w postaci prawnej ochrony życia (art. 38 Konstytucji), prawa do ochrony zdrowia (art. 68 Konstytucji), a także porządku publicznego, które mogłyby być zagrożone w przypadku wzrostu niepokojów społecznych związanych z bardzo dużą liczbą zakażeń SARS-CoV-2 lub rosnącą liczbą przypadków śmierci chorych na COVID-19. Nie ulega zatem najmniejszym wątpliwościom, iż w rozważa-

33 PodkreśliłtoRzecznikPraw Obywatelskichwpiśmiez27 marca2020r.doPrezesaRady Ministrów, pkt 4 (https://www.rpo.gov.pl/sites/default/files/Rozporz\%C4\%85dzenia\%20 MZ\%20COVID-19\%2027.03.2020.pdf).

34 Wyrok Trybunału Konstytucyjnego z 16 stycznia 2007 r., sygn. akt U 5/06, OTK ZU 1A/2007, poz. 3, pkt III.2.2. 
nym przypadku przesłanka materialna ograniczenia korzystania z wolności uzewnętrzniania religii spełnia standard określony w art. 53 ust. 5 Konstytucji (pozytywnie przechodzi ,test drugi”). Jednak fakt ten sam w sobie nie czyni wprowadzonych ograniczeń zgodnymi z Konstytucją ani nie konwaliduje wad popełnionych w obszarze ,pozostałych testów”.

Przechodząc do „trzeciego testu” zasady proporcjonalności wypada najpierw zauważyć, że ograniczenia zawsze powinny „pozostawać w bezpośrednim związku z założonymi celami i w odpowiedniej do nich proporcji, z zachowaniem odpowiedniej wewnętrznej hierarchii wartości konstytucyjnych"35. Rozważając przeto restrykcje dotyczące wolności religii z tej perspektywy, właściwie nie ma wątpliwości - zwłaszcza w świetle jednolitych rekomendacji zarówno polskich, jak i międzynarodowych ekspertów z zakresu epidemiologii (w tym Światowej Organizacji Zdrowia) ${ }^{36}$ - że rozprzestrzenianie się koronawirusa SARS-CoV-2 może zostać ograniczone jedynie poprzez wprowadzenie daleko idących obostrzeń w bezpośrednim kontaktowaniu się między ludźmi, ponieważ patogen przenosi się drogą kropelkową. W konsekwencji uznać należy, że wprowadzenie limitów ilościowych wiernych równocześnie uczestniczących w sprawowaniu kultu religijnego jest przydatne dla osiągnięcia zamierzonego przez prawodawcę celu. Jednak samo stwierdzenie istnienia związku przyczynowo-skutkowego, charakterystycznego dla ,testu” przydatności, nie przesądza o proporcjonalności dyskutowanych tu ograniczeń.

W związku z tym należy ocenić każdy z czterech kolejno wprowadzanych limitów wiernych - 50 osób, 5 wiernych, 1 uczestnik na $15 \mathrm{~m}^{2}$, potem $10 \mathrm{~m}^{2}$ - pod kątem ,testu” konieczności. Prawodawca właściwie w ogóle nie uzasadnił, dlaczego niezbędne było ustanowienie ograniczenia w liczbie uczestników kultu religijnego najpierw do 50, a następnie do 5 osób. Zdaniem wielu specjalistów liczby te zostały określone w sposób arbitralny. Warto w tym miejscu in extenso przytoczyć wypowiedź dr. hab. Tomasza Dzieciątkowskiego, wirusologa z Warszawskiego Uni-

35 Wyrok Trybunału Konstytucyjnego z 29 lipca 2013 r., sygn. akt SK 12/12, OTK ZU 6A/2013, poz. 87, pkt III.7.7.

36 World Health Organization, COVID-19-strategy update, https://www.who.int/docs/ default-source/coronaviruse/covid-strategy-update-14april2020.pdf?sfvrsn=29da3ba0_19 [dostęp: 5.05.2020], s. 5-6. 
wersytetu Medycznego, który na pytanie o uzasadnienie tego rodzaju ograniczeń stwierdził: „Przyznam szczerze, nie wiem. Ograniczenie w takiej sytuacji zgromadzeń jest celowe i rozsądne. Natomiast skąd się wzięły limity, że ulicą mogą iść grupy dwuosobowe, a w posługach religijnych może uczestniczyć 5 osób, a nie 7 czy 10? Przepraszam, ale nie wiem. Zostało to jakoś, prawdopodobnie arbitralnie, wyznaczone przez rząd"37.

Właściwie w tym samym czasie, gdy organy władzy wykonawczej tak drastycznie ograniczały wolność religii, Główny Inspektor Sanitarny zalecał utrzymywanie 2-metrowej odległości pomiędzy osobami ${ }^{38}$. Zważywszy na kubaturę, a zwłaszcza powierzchnię, wielu (jeśli nawet nie większości) polskich świątyń realizacja tego zalecenia była możliwa nawet przy jednoczesnej obecności kilkudziesięciu, a nawet paruset osób. Stąd w niemal każdym kościele mogło pomieścić się zdecydowanie więcej wiernych, niż wynikało z limitu obowiązującego od 25 marca do 19 kwietnia 2020 r. Z punktu widzenia „testu” konieczności, działaniem niezbędnym do zapobieżenia transmisji nowego typu koronawirusa było (jest) zachowanie dystansu przestrzennego między ludźmi. Z tej perspektywy równe potraktowanie wszystkich świątyń, tj. ustanowienie identycznych limitów w każdym kościele trudno uznać za działanie racjonalne. Liczba wiernych mogących równocześnie przebywać w miejscach kultu była bowiem taka sama zarówno w niewielkiej kaplicy, jak i w ogromnej bazylice. Jednolity limit wiernych miał zatem charakter arbitralny i w konsekwencji trudno go uznać za konieczny do zwalczania pandemii, ponieważ inne środki potencjalnie dostępne prawodawcy mogły skuteczniej realizować zakładany przez władzę publiczną cel.

Z punktu widzenia proporcjonalności sensu stricto (adekwatności) nieco inaczej można ocenić limit 50 osób, a inaczej limit 5 wiernych. Ten pierwszy był mniej dolegliwy i nie stanowił tak daleko idącej ingerencji w wolność uzewnętrzniania religii - co nie zmienia faktu, że obydwa zostały dobrane tak samo arbitralnie. Ten drugi należy jednak poddać dużo

37 Wirusolog: Z punktu widzenia zdrowia publicznego, nie ma czegoś takiego, jak demokracja, https:/www.tokfm.pl/Tokfm/7,103085,25817188, wirusolog-z-punktu-widzenia-zdrowia-publicznego-nie-ma-czegos.html [dostęp: 14.04.2020].

384 maja rusza hotele, centra handlowe i rehabilitacja lecznicza, https://www.gov.pl/ web/koronawirus/kolejny-etap [dostęp 5.05.2020]. 
mocniejszej krytyce, ponieważ doprowadził do faktycznego uniemożliwienia sprawowania publicznego kultu religijnego w świątyniach, co można wręcz rozpatrywać w kategoriach naruszenia istoty konstytucyjnej wolności, o której mowa w art. 31 ust. 3 zd. drugie ustawy zasadniczej.

Nieproporcjonalność tej ostatniej restrykcji była szczególnie rażąca w zestawieniu z obostrzeniami wprowadzonymi w tym okresie w innych obszarach, szczególnie w sklepach czy komunikacji miejskiej. Dla przykładu w okresie od 1 kwietnia do 1 maja 2020 r. obowiązywała regulacja, zgodnie z którą w sklepach mogły jednorazowo przebywać 3 osoby na jedno stanowisko kasowe ${ }^{39}$. Przy założeniu, że w niewielkim sklepie o powierzchni $50 \mathrm{~m}^{2}$ znajdują się dwa stanowiska kasowe, oznaczało to, że jednorazowo mogło w nim przebywać 6 osób, a więc 1 osoba na nieco ponad $8 \mathrm{~m}^{2}$. W przypadku czterech stanowisk ta liczba wynosiła 12 , podczas gdy w każdym kościele niezależnie od powierzchni limit wynosił 5 osób (nie licząc osób sprawujących kult). Dysproporcja ta staje się jeszcze większa, jeśli weźmie się pod uwagę limity wprowadzone od 25 marca w środkach publicznego transportu zbiorowego, np. komunikacji miejskiej, zgodnie z którymi można przewozić, w tym samym czasie, nie więcej osób niż wynosi połowa miejsc siedzących ${ }^{40}$. Zważywszy, że standardowy autobus miejski ma długość $12 \mathrm{~m}$ i szerokość 2,5 m oraz znajdują się w nim 44 miejsca siedzące, to przy możliwości zajmowania co drugiego miejsca, okazuje się, iż na 1 osobę przypada $1,36 \mathrm{~m}^{2}$ powierzchni ${ }^{41}$. Nawet jeśli przyjmiemy, że tyle samo miejsc znajduje się w 18-metrowym autobusie przegubowym ${ }^{42}$, to wówczas na 1 osobę przypadnie $2,05 \mathrm{~m}^{2}$

$39 \S 9$ ust. 5 pkt 1 rozporządzenia Rady Ministrów z 31 marca, potem $\S 9$ ust. 6 pkt 1 rozporządzenia Rady Ministrów z 10 kwietnia, następnie $\S 9$ ust. 5 pkt 1 rozporządzenia Rady Ministrów z 19 kwietnia.

40 Na podstawie § 3a rozporządzenia Ministra Zdrowia z 20 marca 2020 r. zmieniającego rozporządzenie w sprawie ogłoszenia na obszarze Rzeczypospolitej Polskiej stanu epidemii.

41 Por. podpisany przez kilkunastu profesorów i doktorów inżynierów, datowany na 26 marca 2020 r. wniosek do Ministra Zdrowia, dostępny pod adresem https://wilis.pg.edu. pl/documents/10683/100294447/Wniosek\%20o\%20zmiane\%20Rozporzadzenia\%20-\%20 Dz.U.\%202020\%20poz.\%20491-prof\%20zauf\%20\%281\%29.pdf [dostęp: 14.05.2020].

42 Koronawirus, Warszawa. Rośnie liczba pasażerów w komunikacji miejskiej. Trzaskowski apeluje o zmiany w obostrzeniach, https:/warszawa.naszemiasto.pl/koronawirus-warszawa-rosnie-liczba-pasazerow-w-komunikacji/ar/c1-7670451 [dostęp: 14.05.2020]. 
powierzchni. Tymczasem w świątyniach analogiczny współczynnik wynosił, przykładowo, od 1 wiernego na $10 \mathrm{~m}^{2} \mathrm{w}$ niewielkim kościółku przez 1 wiernego na $200 \mathrm{~m}^{2} \mathrm{w}$ dużym kościele, po 1 wiernego na $1000 \mathrm{~m}^{2}$ lub więcej w największych katedrach i bazylikach ${ }^{43}$. To z kolei jasno dowodzi nieproporcjonalności (nieadekwatności) tak drastycznego ograniczenia uczestnictwa w publicznym sprawowaniu kultu. Z pewnością tak rygorystycznych limitów nie uzasadniają względy sanitarne, ponieważ nie ma dowodów na to, że większe prawdopodobieństwo zakażenia się koronawirusem jest w kościele niż w autobusie czy sklepie. Jest to tym bardziej rażące naruszenie, iż w świetle aksjologii i hierarchii wartości konstytucyjnych obostrzenia w tym zakresie powinny być wprowadzane w mniejszym stopniu niż gdzie indziej.

Nieco inaczej należy ocenić obowiązującą od 20 kwietnia 2020 r. regułę: 1 wierny na $15 \mathrm{~m}^{2}$ powierzchni świątyni (podkreślić trzeba, że zgodnie z $§ 9$ ust. 1 pkt 3 lit. b rozporządzenia z 19 kwietnia, następnie $\S 8$ ust. 1 pkt 3 lit. a rozporządzenia z 2 maja, limit należało obliczać z uwzględnieniem powierzchni całego budynku, a nie jedynie części, w której zwyczajowo przebywają wierni). Co do zasady, restrykcję tę należy uznać za analogiczną względem wprowadzonych w innych obszarach życia społecznego, jak np. w sklepach liczących ponad $100 \mathrm{~m}^{2}$ powierzch$\mathrm{ni}^{44}$. Z perspektywy „trzeciego testu” ograniczenie to wypada potraktować zatem nie tylko jako przydatne, lecz również jako konieczne i adekwatne, choć w zestawieniu z małymi sklepami i komunikacją miejską, których reguły funkcjonowania zostały przedstawione w poprzednim akapicie, można żywić pewne wątpliwości w tym zakresie. Tymczasem, co wymaga ponownego podkreślenia, w świetle konstytucyjnej aksjologii wszelkie obostrzenia w korzystaniu z wolności religii muszą być - jeżeli już - wprowadzane w ostatniej kolejności, a nie w pierwszej czy drugiej. Dotyczy to również konieczności ich znoszenia w pierwszej kolejności, a nie ostatniej.

43 Dla przykładu w Sanktuarium Matki Bożej Licheńskiej tylko powierzchnia użytkowa bazyliki górnej wynosi $7009 \mathrm{~m}^{2}$ - http://www.lichen.pl/pl/24/n_2289/wieksza_liczba_wiernych_w_bazylice [dostęp: 14.05.2020].

$44 \S 9$ ust. 6 pkt 1 rozporządzenia z 19 kwietnia. 
W tym kontekście pozytywnie trzeba ocenić wprowadzenie 2 maja ${ }^{45}$ stałego limitu 5 wiernych $\mathrm{w}$ świątyniach o powierzchni poniżej $75 \mathrm{~m}^{2}$ (od 17 maja - $50 \mathrm{~m}^{2}$ ), w których na skutek zmian obowiązujących od 20 kwietnia 2020 r. restrykcje w sprawowaniu kultu religijnego stały się jeszcze bardziej dolegliwe. W świetle „trzeciego testu” zasady proporcjonalności wprowadzenie reguły: 1 wierny na $10 \mathrm{~m}^{2}$ powierzchni świątyni (od 17 maja $)^{46}$, również zakwalifikować należy jako krok we właściwym kierunku, choć zważywszy na fakt, że odbywało się to równolegle z luzowaniem ograniczeń w innych obszarach, trudno uznać, iż hierarchia konstytucyjnych wolności i praw została zachowana.

Wątpliwości w świetle „testu trzeciego” zasady proporcjonalności nie budzi natomiast obowiązek zakrywania ust i nosa także w trakcie sprawowania kultu religijnego (z wyjątkiem sprawującego kult religijny podczas jego celebracji, czyli np. kapłana przewodniczącego mszy św. czy ministranta śpiewającego psalmy ${ }^{47}$. Obostrzenie to jest przydatne do osiągnięcia celu, jakim jest minimalizowanie zagrożenia zakażeniem koronawirusem SARS-CoV-2 i adekwatne w stosunku do uciążliwości, jakie ze sobą niesie. Można je również uznać za konieczne, zważywszy że analogiczny obowiązek został wprowadzony niemal powszechnie w miejscach publicznych ${ }^{48}$.

Podsumowując zatem ocenę ilościowych restrykcji w sprawowaniu publicznego kultu religijnego w ramach przeciwdziałania rozwojowi pandemii koronawirusa SARS-CoV-2 przez pryzmat konstytucyjnej zasady proporcjonalności należy stwierdzić, iż zostały wprowadzone w sposób niezgodny z art. 53 ust. 5 oraz art. 31 ust. 3 w zw. z art. 53 ust. 2 Konstytucji. Wszystkie ustanowiono w drodze rozporządzenia, wydanego bez upoważnienia ustawowego, co pozostaje w sprzeczności z formalną przesłanką limitacji jedynie w formie ustawy (niespełnienie ,pierwszego testu”). Ponadto określenie „sztywnych” granic dopuszczalnej obecności wiernych w świątyniach (50 i 5 osób), nie było ani niezbędne dla ochrony zdrowia

45 Na mocy $\S 8$ ust. 1 pkt 3 lit. a rozporządzenia z 2 maja.

$46 \mathrm{Na}$ mocy $\S 8$ ust. 1 pkt 3 lit. b rozporządzenia z 16 maja.

47 Wynikający np. z rozporządzeń z 19 kwietnia czy z 2 maja ( $\$ 18$ ust. 1 pkt 2 lit. b).

48 Np. $\$ 18$ ust. 1 rozporządzenia z 19 kwietnia. Obowiązek ten został utrzymany na mocy $\S 18$ ust. 1 rozporządzenia z 2 maja i $§ 17$ ust. 1 rozporządzenia z 16 maja. 
czy jakiejkolwiek innej wartości wymienionej w art. 53 ust. 5 Konstytucji, ani adekwatne do zamierzonego celu, zwłaszcza limit 5 wiernych w jednej świątyni (niespełnienie ,trzeciego testu”). Poza tym wszystkie te ograniczenia (a więc także 1 osoba na 15 lub $10 \mathrm{~m}^{2}$ ) - aczkolwiek w różnym stopniu - nie uwzględniały wysokiej rangi wolności religii $\mathrm{w}$ hierarchii wartości konstytucyjnych, zwłaszcza te obowiązujące od 25 marca do 19 kwietnia 2020 r. Konstatacji tej nie zmienia ani okoliczność, że analizowane ograniczenia $\mathrm{w}$ korzystaniu $\mathrm{z}$ wolności uzewnętrzniania religii wprowadzone zostały ze względu na co najmniej jedną z wartości wymienionych w art. 53 ust. 5 Konstytucji (ochronę zdrowia), ani fakt, iż same w sobie pozostają przydatne do osiągnięcia zamierzonego przez prawodawcę celu, ponieważ każde ograniczenie konstytucyjnej wolności lub prawa musi spełniać wszystkie przesłanki warunkujące jego dopuszczalność - każdy z „trzech testów” zasady proporcjonalności.

Niezależnie od braku legalności omawianych tu restrykcji, trzeba także zauważyć wadliwość mechanizmów sankcyjnych zapewniających ich egzekwowanie przez organy państwowe ${ }^{49}$. Co prawda art. 48a ustawy o zwalczaniu chorób zakaźnych przewiduje administracyjne kary pieniężne za nieprzestrzeganie ograniczeń wymienionych w tej ustawie, a sprecyzowanych w rozporządzeniach kolejno wydawanych w stanie zagrożenia epidemicznego lub epidemii, to jednak ta ustawa - jak była mowa o tym wyżej - nie wprowadza ani nie dopuszcza żadnych ograniczeń w korzystaniu z wolności uzewnętrzniania religii. Stąd ewentualnie nałożenie kary administracyjnej za nieprzestrzeganie limitu wiernych odbyło się bez podstawy prawnej (co oczywiście nie znaczy, że nie mogło mieć miejsca).

Za podstawę prawną do wymierzenia duchownym lub wiernym sankcji nie można uznać także art. 54 Kodeksu wykroczeń ${ }^{50}$. Przepis ten ustanawia sankcję - w postaci grzywny do 500 złotych lub nagany - dla tego, kto wykracza przeciwko wydanym z upoważnienia ustawy przepisom porządkowym o zachowaniu się w miejscach publicznych. Jednak regulacja ta nie znajduje zastosowania w sytuacji, gdy przepisy porządkowe zostały

49 Chyba że owa wadliwość jest swoistym sposobem respektowania wysokiego miejsca wolności religii w hierarchii wartości konstytucyjnych, ponieważ pozwala na uchylenie się od sankcji.

50 Ustawa z dnia 20 maja 1971 r. - Kodeks wykroczeń, Dz. U. z 2019 r., poz. 821. 
wydane $\mathrm{z}$ naruszeniem upoważnienia ustawowego ${ }^{51}$. Prawidłowość wydania tego rodzaju aktów podustawowych zawsze powinna być oceniania przez sąd, który - jak wiadomo - w orzekaniu związany jest jedynie Konstytucją i ustawami (art. 178 ust. 1 Konstytucji). Dlatego w przypadku stwierdzenia niezgodności z ustawą, nie mogą one znaleźć zastosowania $\mathrm{w}$ danej sprawie ${ }^{52}$. Biorąc pod uwagę przytoczone wyżej argumenty, nie może być wątpliwości, że ograniczające wolność religii przepisy rozporządzeń wydawanych w związku z wprowadzeniem w Polsce stanu epidemii, a wcześniej stanu zagrożenia epidemicznego, nie znajdują zastosowania w sprawach wykroczeniowych.

\section{OGRANICZANIE WOLNOŚCI RELIGII \\ A ZASADA AUTONOMII I NIEZALEŻNOŚCI ZWIĄZKÓW RELIGIJNYCH}

Egzekwowanie - tak jak ustanawianie - wszelkich obostrzeń w kulcie religijnym musi również uwzględniać pozycję ustrojową kościołów i innych związków wyznaniowych, a zwłaszcza ich autonomię oraz niezależność, która niewątpliwie wzmacnia konstytucyjną ochronę wolności religii, szczególnie na terenie świątyni. Zgodnie z art. 25 ust. 3 Konstytucji stosunki między państwem a kościołami i innymi związkami wyznaniowymi są kształtowane na zasadach poszanowania ich autonomii oraz wzajemnej niezależności każdego w swoim zakresie, jak również współdziałania dla dobra człowieka i dobra wspólnego. Przepis ten wyraźnie więc ogranicza swobodę samego ustawodawcy zwykłego w ingerowaniu w sprawowanie kultu religijnego. Wynika to $\mathrm{z}$ faktu, iż odgrywa on nie tylko jedną z kluczowych ról w ochronie wolności religii, lecz przede wszystkim stwarza prawne gwarancje funkcjonowania związków wyznaniowych. W swoim podstawowym znaczeniu autonomia oraz wzajemna niezależność związków religijnych oznacza zdolność wspólnot konfesyjnych do tworzenia i rządzenia się własnym prawem wewnętrznym ${ }^{53}$. W konsekwencji ustrojodawca zdecydował, że związki religijne prawo

\footnotetext{
51 Budyn-Kulik 2019, pkt 1.

52 Wyrok Sądu Najwyższego z 9 czerwca 2005 r., sygn. akt V KK 41/05.

53 Krukowski 1993, 82-98; Garlicki 2007, uwaga 13; Olszówka 2016c, 154-174.
} 
to na zasadzie wyłączności realizują w „swoim zakresie”, a więc przede wszystkim w ramach działalności, w których realizują funkcję religijną, czyli określają prawa i obowiązki wiernych, kwestie doktrynalne, zasady sprawowania obrzędów i udzielania posług religijnych (a tym samym definiowania kto i na jakiej podstawie może z nich korzystać), zasad propagowania wyznawanej wiary, a także określania kryteriów przynależności do wspólnoty i sposobów zarządzania nią, tworzenia materialnych warunków jej działalności oraz podejmowania inicjatyw wynikających z wyznawanej doktryny ${ }^{54}$. To z kolei oznacza, że regulowanie spraw dotyczących zasad celebrowania kultu religijnego oraz warunków uczestnictwa w nim znajduje się poza jurysdykcją jakichkolwiek organów państwowych ${ }^{55}$. W świetle art. 25 ust. 3 Konstytucji to właściwa władza kościelna jest uprawniona do zmiany zasad sprawowania kultu religijnego, udzielania dyspens od obowiązków wynikających z wyznawanej wiary czy wprowadzania innych zarządzeń i rozstrzygnięć, które są stosowne do zaistniałej sytuacji.

Egzemplifikacją tej konsekwencji zasady autonomii oraz wzajemnej niezależności jest fakt, że w związku z pojawieniem się koronawirusa SARS-CoV-2 w Polsce związki religijne - niezależnie od decyzji władz państwowych - we własnym zakresie wdrażały rozwiązania mające na celu zminimalizowanie ryzyka zakażenia podczas publicznego sprawowania kultu religijnego. Przykładowo biskup gliwicki Jan Kopiec 14 marca 2020 r. - a więc w czasie, gdy w świetle rozporządzeń władzy wykonawczej we mszach św. mogło uczestniczyć do 50 osób - wydał dekret, na mocy którego postanowiono m.in. o odprawianiu mszy św. bez udziału wiernych świeckich i odwołaniu nabożeństw pasyjnych (Gorzkich Żali i Drogi Krzyżowej) ${ }^{56}$. Podobną decyzję podjął 24 marca 2020 r. biskup tarnowski Andrzej Jeż, zastrzegając że we mszy św. w ramach ówcześnie obowiązującego limitu 5 wiernych mogli uczestniczyć jedynie zamawiający intencję, po wcześniejszym uzgodnieniu tego faktu z proboszczem. Jednocześnie celebracja nabożeństw z udziałem wiernych została zakaza-

54 Stanisz 2011, 82-83; Borecki 2012, 89-109.

55 Stanisz 2015, 166 i 169.

56 Dekretzdnia 14 marca 2020r., https://kuria.gliwice.pl/2020/03/14/dekret-14-03-2020/ [dostęp: 9.05.2020]. 
na ${ }^{57}$. Warto nadmienić, że w diecezjach tarnowskiej i gliwickiej możliwość sprawowania mszy św. ,z udziałem ludu” została przywrócona dopiero 20 kwietnia $2020 \mathrm{r}^{58}$ Należy również podkreślić, iż w ślad za jednoznacznymi wskazówkami Prezydium Konferencji Episkopatu Polski ${ }^{59}$ we wszystkich diecezjach została udzielona dyspensa od obowiązku uczestnictwa we mszy św. niedzielnej i w święta nakazane. Z tego tytułu wierni nie zostali narażeni na konflikt sumienia zachodzący w przypadku ograniczenia możliwości uczestnictwa w liturgii wyłącznie przez władze państwowe.

Podobne rozwiązania zostały wprowadzone przez inne związki religijne. Przykładowo Kościół Ewangelicko-Augsburski na czas pandemii zupełnie zawiesił celebrację wszystkich swoich nabożeństw oraz spotkań parafialnych $^{60}$, a Muzułmański Związek Religijny w Rzeczypospolitej Polskiej ograniczył modlitwy w zarządzanych przez siebie świątyniach polecając ich praktykowanie wiernym w domach ${ }^{61}$. Przykłady powyższe doskonale ilustrują zatem tezę, że związki religijne - z pełnym poszanowaniem zasad ustrojowych Rzeczypospolitej Polskiej i niezależnie od władz

57 Dekret Biskupa Tarnowskiego w związku ze stanem epidemii w Polsce, https://diecezja.tarnow.pl/index.php/wiadomosci/item/7573-dekret-biskupa-tarnowskiego-w-zwiazku-ze-stanem-epidemii-w-polsce-24-03-2020 [dostęp: 9.05.2020].

58 Zarządzenie Biskupa Tarnowskiego w związku z Rozporządzeniem Rady Ministrów w sprawie ustanowienia określonych ograniczeń, nakazów i zakazów w związku z wystąpieniem stanu epidemii, https://diecezja.tarnow.pl/index.php/wiadomosci/item/7646-zarzadzenie-biskupa-tarnowskiego-w-zwiazku-z-rozporzadzeniem-rady-ministrow-18-04-2020 [dostęp: 9.05.2020]; Wskazania Biskupa Gliwickiego z dnia 19 kwietnia 2020 r., https:// kuria.gliwice.pl/2020/04/19/wskazania-biskupa-gliwickiego/ [dostęp: 9.05.2020].

59 Zarządzenie nr 1/2020 Rady Stałej Konferencji Episkopatu Polski, https://episkopat.pl/zarzadzenie-nr-1-2020-rady-stalej-konferencji-episkopatu-polski-z-dnia-12-marca-2020-r/ [dostęp: 9.05.2020]; Wskazania Prezydium Konferencji Episkopatu Polski dla Biskupów odnośnie do sprawowania czynności liturgicznych w najbliższych tygodniach, https://episkopat.pl/prezydium-episkopatu-przypominamy-o-koniecznosci-udzielenia-kolejnej-dyspensy-2/ [dostęp: 9.05.2020].

60 Nadzwyczajne zasady życia parafialnego w czasie pandemii, https://www.luteranie. pl/files/2.Nadzwyczajnezasadyyciaparafialnegowczasachpandemii.pdf [dostęp: 9.05.2020].

${ }^{61}$ Oświadczenie Najwyższego Kolegium Muzułmańskiego Muzułmańskiego Związku Religijnego w RP, mzr.pl/oswiadczenie-najwyzszego-kolegium-muzulmanskiego-muzulmanskiego-zwiazku-religijnego-w-rzeczypospolitej-polskiej/ [dostęp: 9.05.2020]. 
państwowych - są w stanie samodzielnie wprowadzić regulacje przeciwdziałające rozszerzaniu się epidemii.

Z pewnością ustawowa limitacja zakresu autonomii oraz wzajemnej niezależności związku religijnego jest konstytucyjnie dopuszczalna, niemniej w demokratycznym państwie prawnym (art. 2 Konstytucji) zawsze wymaga wyraźnej regulacji ustawowej (lub w umowie międzynarodowej o wyższej mocy prawnej niż ustawa), uzasadnionej koniecznością realizacji odpowiednio doniosłych wartości i zasad konstytucyjnych. Dotyczy to zwłaszcza związków religijnych o indywidualnie uregulowanej sytuacji prawnej (o których mowa w art. 25 ust. 4 i 5 Konstytucji). Nie przesądzając w tym miejscu, czy wprowadzone w związku z przeciwdziałaniem epidemii COVID-19 restrykcje w sprawowaniu kultu religijnego w ogóle są dopuszczalne w świetle art. 25 ust. 3 Konstytucji (i art. 233 zakazującego wprowadzenia dodatkowych ograniczeń w korzystaniu z wolności religii w stanach nadzwyczajnych, które należy traktować jako zezwalające na dalej idące ingerencje w konstytucyjne wolności i prawa niż stany zagrożenia epidemicznego czy epidemii), należy z całą pewnością skonstatować, że musiałyby być wprost zawarte w ustawie, a nigdy w rozporządzeniu, co potwierdza i wzmacnia wnioski płynące $\mathrm{z}$ analizy na gruncie art. 31 ust. 3 i 53 ust. 5 Konstytucji ${ }^{2}$.

Konsekwencją zasady ustrojowej zawartej w art. 25 ust. 3 Konstytucji jest również to, iż organy władzy publicznej nie mają ani uprawnień, ani stosownych instrumentów, aby ingerować w wewnętrzne sprawy związków religijnych, w tym badać, ile osób znajduje się wewnątrz świątyni w czasie sprawowania kultu. Jej uszczegółowienie w dyskutowanym tu obszarze w stosunku do Kościoła Katolickiego znajduje się w art. 8 Konkordatu $^{63}$. Zgodnie z ust. 3 tego przepisu Polska zobowiązała się zapewnić nienaruszalność miejscom przeznaczonym przez właściwą władzę kościel-

62 Warto zwrócić uwagę, że skutecznym środkiem przeciwdziałania epidemii może okazać się zakaz przemieszczania się ponad określoną odległość od miejsca zamieszkania, który z jednej strony w sposób całkiem efektywny powinien powstrzymać transmisję patogenu, a z drugiej strony pozwoli uniknąć, przynajmniej formalnie, wprowadzenia restrykcji tam gdzie to konstytucyjnie niedopuszczalne, nawet jeśli ubocznym skutkiem tego środka będzie faktyczne ograniczenie korzystania z innych wolności.

63 Konkordat między Stolicą Apostolską i Rzecząpospolitą Polską, podpisany w Warszawie dnia 28 lipca 1993 r., Dz. U. z 1998 r. Nr 51, poz. 318. 
ną do sprawowania kultu i grzebania zmarłych. Z leksykalnego punktu widzenia rzeczownik „,nienaruszalność” pochodzi od przymiotnika „nienaruszalny”, a więc „taki, którego nie można naruszyć, zmienić” ${ }^{64}$, co nakazuje z dużą ostrożnością podchodzić w ogóle do możliwości interwencji czy ingerencji policji w sprawowane w kościele nabożeństwo. W tym kontekście należy zaznaczyć, że art. 8 Konkordatu dotyczy organizowania kultu przez Kościół Katolicki, przy czym Rzeczpospolita Polska jednoznacznie zapewniła Kościołowi wolność sprawowania kultu (art. 8 ust. 1), który jest organizowany zgodnie z przepisami prawa kanonicznego i z zachowaniem odpowiednich przepisów prawa polskiego (art. 8 ust. 2). Oczywiście tych, które są zgodne z Konstytucją, ponieważ Konkordat - podobnie jak każda inna umowa międzynarodowa - nie może zmienić reguł rządzących systemem źródeł prawa.

Ponadto Konkordat zastrzega, że interwencja władz publicznych w miejscach kultu, którym zagwarantowano nienaruszalność, może nastąpić tylko po uprzednim powiadomieniu władzy kościelnej (co jednak należy rozumieć jako formę wniosku o zezwolenie ${ }^{65}$ ) lub jeśli jest to konieczne dla ochrony życia, zdrowia lub mienia (art. 8 ust. 5). Ta druga możliwość została ustanowiona jako wyjątek, a zatem - zgodnie z kanonami wykładni - musi być intepretowana zawężająco. Stąd możliwość przewidziana w art. 8 ust. 5 in fine Konkordatu aktualizuje się dopiero w przypadku rzeczywistego - a nie jedynie potencjalnego - zagrożenia któregoś ze wskazanych trzech podstawowych dóbr, a jednocześnie nie może istnieć możliwość usunięcia zagrożenia w drodze innych, mniej dotkliwych sposobów, np. strzelanina wewnątrz świątyni, pościg za złodziejem, pożar. Do takich sytuacji naglącej konieczności ${ }^{66}$, które umożliwiałyby wkroczenie policji do kościoła, z pewnością nie należy domniemane lub nawet wysoce prawdopodobne przekroczenie wynikającej z rządowych rozporządzeń liczby wiernych przebywających równocześnie w świątyni. Na gruncie art. 8 ust. 5 Konkordatu byłaby natomiast dopuszczalna interwencja w sytuacji, gdyby w świątyni znajdowała się osoba objęta kwarantanną,

64 Słownik języka polskiego PWN, https://sjp.pwn.pl/sjp/nienaruszalny;2489054.html [dostęp: 30.04.2020].

65 Krukowski 2008, 141.

66 Krukowski 2019, 259. 
izolacją, obowiązkiem hospitalizacji lub zakażona koronawirusem SARS-CoV-2 (ale już nie: podejrzewana o to lub potencjalnie mogąca być taką). Należy także zaznaczyć, że tego rodzaju interwencja zawsze musi być podejmowana na podstawie przepisów prawa, spełniających warunki przewidziane dla limitacji korzystania z wolności religii.

\section{WNIOSKI}

Zgodnie z zasadą proporcjonalności ograniczenia w korzystaniu z konstytucyjnych wolności i praw mogą nastąpić jedynie po spełnieniu warunków formalnych i materialnych, na które składają się trzy podstawowe kryteria, tj. obostrzenia muszą być: przewidziane w ustawie (,pierwszy test"), wprowadzone w celu ochrony jednej z wartości wymienionych w Konstytucji (,drugi test”) oraz przydatne, konieczne i adekwatne, czyli proporcjonalne sensu stricto („trzeci test”), i nie mogą naruszać istoty poddanej limitacji wolności (prawa). Niespełnienie któregokolwiek z tych warunków oznacza niezgodność regulacji z Konstytucją.

Wprowadzone w czasie pandemii koronawirusa SARS-CoV-2 restrykcje dotyczące wolności uzewnętrzniania religii - pomimo uczynienia zadość „drugiemu testowi” - nie spełniały bezdyskusyjnie „pierwszego testu” (forma aktu normatywnego) oraz ,trzeciego testu”, choć ze zmiennym nasileniem, ponieważ niekonieczność i nieadekwatność ustanawianych kolejno obostrzeń występowała z różną intensywnością.

Oczywiście nie ma wątpliwości, iż sposób postępowania prawodawcy przeciwdziałającego skutkom pandemii powinien być podyktowany względami epidemiologicznymi, jednak posiadanie nawet dostatecznych racji samo w sobie nie uprawnia organów państwa do wprowadzania każdego rodzaju obostrzeń w dowolny sposób. Prawodawca powinien wprowadzać minimalne (optymalne) ograniczenia, które byłyby niezbędne (konieczne) do osiągnięcia celu w postaci ochrony zdrowia publicznego. Uwzględniwszy wspomniane już racje medyczne, a także społeczne, prawodawca nade wszystko musi respektować hierarchię wartości konstytucyjnych, w tym wolności i praw, oraz zapewnić należyte poszanowanie tych o charakterze fundamentalnym, jak np. wolność religii, której ograniczenia powinny następować w ostatniej, a nie pierwszej czy drugiej kolejności. Dotyczy to 
zarówno fazy nakładania, jak i etapu łagodzenia restrykcji. Tak jak w okresie trwającej pandemii COVID-19 nie rozważano zamykania sklepów spożywczych i aptek, a bez wahania zawieszono działalność klubów fitness, siłowni czy salonów kosmetycznych, tak odpowiednio należy miarkować obostrzenia zwłaszcza w tych obszarach życia społecznego, którym ustrojodawca zapewnił szczególną ochronę. Oczywiście zakres i intensywność restrykcji będą mniejsze lub większe, w zależności od regresu lub progresu epidemii, lecz zawsze muszą uwzględniać aksjologiczny i normatywny porządek (kolejność) ich wprowadzania oraz zachowywać racjonalne proporcje, co właśnie wynika z Konstytucji RP z 1997 r.

\section{BIBLIOGRAFIA}

Borecki, Paweł. 2012. „Autonomia kościołów i innych związków wyznaniowych we współczesnym prawie polskim". Studia z Prawa Wyznaniowego 15: 89-109.

Budyn-Kulik, Magdalena. 2019. „Objaśnienia do art. 54 Kodeksu wykroczeń”. W: Kodeks wykroczeń. Komentarz, red. Paweł Daniluk. Warszawa: C.H. Beck. Garlicki, Lech, Krzysztof Wojtyczek. 2016. „Objaśnienia do art. 31 Konstytucji RP”. W: Konstytucja RP. Komentarz. Tom II, red. Leszek Garlicki, Marek Zubik. Warszawa: Lex.

Garlicki, Lech. 2012. Polskie prawo konstytucyjne. Zarys wyktadu. Warszawa: Wolters Kluwer.

Garlicki, Lech. 2007. „Komentarz do art. 25 Konstytucji RP”. W: Konstytucja Rzeczypospolitej Polskiej. Komentarz, t. V, red. Leszek Garlicki. Warszawa: Wydawnictwo Sejmowe.

Krukowski, Józef. 1993. Kościót i państwo. Podstawy relacji prawnych. Lublin: Redakcja Wydawnictw KUL.

Krukowski, Józef. 2008. Polskie prawo wyznaniowe. Warszawa: Wolters Kluwer. Krukowski, Józef. 2019. „Wolność kultu publicznego”. W: Konkordaty polskie. Historia i teraźniejszość, red. Józef Krukowski, 240-269. Lublin: Wydawnictwo KUL.

Olszówka, Marcin. 2016a. „Objaśnienia do art. 25 Konstytucji RP”. W: Konstytucja RP. Tom I. Komentarz do art. 1-86, red. Marek Safjan, Leszek Bosek. Warszawa: C.H. Beck. 
Olszówka, Marcin. 2016b. „Objaśnienia do art. 53 Konstytucji RP”. W: Konstytucja RP. Tom I. Komentarz do art. 1-86, red. Marek Safjan, Leszek Bosek. Warszawa: C.H. Beck.

Olszówka, Marcin. 2016c. Wptyw Konstytucji RP z 1997 roku na system źródet prawa wyznaniowego. Warszawa: Wydawnictwo Uczelni Łazarskiego.

Stanisz, Piotr. 2011. „Zasada autonomii i niezależności”. W: Artur Mezglewski, Henryk Misztal, Piotr Stanisz. Prawo wyznaniowe, 80-83. Warszawa: C.H. Beck.

Stanisz, Piotr. 2015. „Konstytucyjne zasady określające relacje państwa z kościołami i innymi związkami wyznaniowymi: autonomia i niezależność oraz współdziałanie". W: Katolickie zasady relacji państwo-Kościól a prawo polskie, red. Józef Krukowski, Mirosław Sitarz, Henryk Stawniak, 150-170. Lublin: Wydawnictwo KUL.

Tuleja, Piotr. 2019. „Komentarz do art. 31 Konstytucji RP”. W: Konstytucja Rzeczypospolitej Polskiej. Komentarz, red. Piotr Tuleja. Warszawa: Lex.

Wojtyczek, Krzysztof. 1999. Granice ingerencji ustawodawczej w sferę praw człowieka w Konstytucji RP. Kraków: Kantor Wydawniczy „Zakamycze”.

\section{AN ANALYSIS OF THE CONSTITUTIONALITY OF RESTRICTIONS ON THE EXERCISE OF FREEDOM OF RELIGION DURING THE CORONAVIRUS PANDEMIC IN POLAND}

\section{Abstract}

The need to prevent the development of the SARS-CoV-2 coronavirus pandemic makes it necessary to maintain physical distance to comply with various types of sanitary standards. However, when restrictions imposed by public authorities lead to limiting the exercise of human rights and freedoms, they must be laid down in normative acts of appropriate form and content. Meanwhile, many of the restrictions introduced by the Polish authorities with a view to combatting the pandemic, which restricted the exercise of freedom of religion, did not meet the standards defined by the Polish Constitution.

Key words: freedom of religion; legality of restrictions on the exercise of freedom of religion; pandemic; COVID-19; proportionality principle; autonomy of religious organizations 
